\title{
nejpec
}

\section{Políticas Públicas de Economia Solidária: uma Revisão da Literatura}

\section{Fernanda Machado Ferreira}

Mestre em Administração Pública pelo PROFIAP/UFG

E-mail: ufg.fer@gmail.com

Leandro Lombardi

Mestre em Administração Pública pelo PROFIAP/UFG

E-mail: leolombardi@gmail.com

\section{Maico Roris Severino}

Professor de Engenharia da Produção

PROFIAP/UFG

E-mail:maicororis@gmail.com

\author{
Cláudia Regina Rosal Carvalho \\ Professora de Economia \\ Universidade Federal de Goiás - FACE/UFG e PROFIAP/UFG \\ E-mail: clregina@hotmail.com
}

\section{Flávia Rezende Campos \\ Professora de Economia \\ Universidade Federal de Goiás - FACE/UFG \\ E-mail: flaviarezende@hotmail.com}

Resumo: A Economia Solidária é um movimento que cresce no Brasil como forma de inclusão social e geração de renda. No entanto, esse tipo de economia ainda carece de mecanismos de apoio e consolidação de políticas públicas para o fortalecimento dessas práticas. Desse modo, o objetivo desse estudo foi realizar uma revisão da literatura da produção de estudos científicos sobre políticas públicas de economia solidária a fim de verificar quais as políticas públicas foram criadas no âmbito federal, estadual e municipal para fomentar a Economia Solidária. Para tanto, foi realizado um levantamento bibliográfico com o propósito exploratório e descritivo, considerando uma abordagem qualitativa dos estudos científicos analisados. Os resultados obtidos demonstram que ações políticas de fomento a esse tipo de economia têm abrangência nas três esferas governamentais e vem conseguindo apoio crescente dos governos. Esses avanços são essenciais para a consolidação da economia solidária como estratégia e política de desenvolvimento.

Palavras-chave: Políticas Públicas. Economia Solidária. Desenvolvimento. 
Abstract: The Solidarity Economy is a movement that grows in Brazil as a form of social inclusion and income generation. However, this type of economy still lacks mechanisms to support and consolidate public policies to strengthen these practices. Thus, the aim of this study was to conduct a literature review of the production of scientific studies on public policies of solidarity economy in order to verify which public policies were created at the federal, state and municipal levels to foster Solidary Economy. To this end, a bibliographic survey was conducted with exploratory and descriptive purpose, considering a qualitative approach of the scientific studies analyzed. The results show that political actions to foster this type of economy have coverage in the three governmental spheres and have been getting increasing support from governments. These advances are essential for the consolidation of the solidarity economy as a development strategy and policy.

Key words: Public policy. Solidarity economy. Development

JEL Code: 021,01

\section{INTRODUÇÃO}

"A Economia Solidária é um jeito diferente de produzir, vender, comprar e trocar o que é preciso para viver. Sem explorar os outros, sem querer levar vantagem, sem destruir o ambiente (BRASIL-MTE, 2015, p.1)."

Esse tipo de economia surge como uma forma de organização do trabalho que busca minimizar as desigualdades sociais propagando valores de cooperação e solidariedade, já que o sistema econômico predominante na sociedade, apesar de possuir grande capacidade de geração de renda, evolui de forma desigual.

Diante desse contexto socioeconômico no Brasil, a economia solidária enfrenta grandes dificuldades, principalmente, para a inserção no mercado e para mobilizar um percentual maior de pessoas, e assim, seus atores têm chamado atenção para a vulnerabilidade dessa economia e para a necessidade do apoio e fomento das políticas públicas para intervir de forma a diminuir as dificuldades e suscitar a conscientização sobre o importante papel da economia solidária (NEVES, 2014).

Segundo Silva (2009), saber o papel do Estado em todas as esferas governamentais, conhecendo a forma como ele se insere e quais são as estratégias para a formulação de políticas públicas, é essencial para se ter maior abrangência das iniciativas de fomento à economia solidária.

E assim, ciente da importância da atuação do poder público na esfera da economia solidária, o objetivo desse estudo foi realizar uma revisão da literatura da produção de estudos científicos sobre políticas públicas de economia solidária a fim de verificar quais as políticas públicas foram criadas no âmbito federal, estadual e municipal para fomentar a Economia Solidária.

Para atingir o objetivo, realizou-se uma pesquisa bibliográfica com caráter exploratório e descritivo, extraindo-se nos estudos científicos, os programas governamentais que foram concebidos diretamente no contexto do movimento da economia solidária. 
O presente trabalho apresenta a seguinte estrutura: aspectos teóricos permeando sobre políticas públicas, economia solidária como estratégia de desenvolvimento e políticas públicas de economia solidária. Em seguida, os aspectos metodológicos, os resultados e discussões encontrados e as considerações finais do estudo.

\section{POLÍTICAS PÚBLICAS}

No Brasil, a área de conhecimento de políticas públicas surge com transição do autoritarismo para a democracia, entre os anos de 1970 e 1980, momento também marcado pela institucionalização das ciências sociais que foram fundamentais para os aspectos específicos dessa área de estudos (HOCHMAN; ARRETCHE; MARQUES, 2007).

O conceito em si sobre políticas públicas não é único e não há uma melhor definição, e Souza (2007) fez uma comparação dessas principais definições sobre políticas públicas, conforme pode ser apresentada pelo quadro 1:

Quadro 1: Conceito de Políticas Públicas pelos principais autores.

\begin{tabular}{|cl|}
\hline AUTOR & \multicolumn{1}{c|}{ CONCEITO DE POLÍTICAS PÚBLICAS } \\
\hline Mead (1995) & $\begin{array}{l}\text { Campo dentro do estudo da política que analisa o governo à luz de grandes } \\
\text { questões públicas. }\end{array}$ \\
\hline Lynn (1980) & Conjunto de ações do governo que irão produzir efeitos específicos. \\
Peters (1986) & $\begin{array}{l}\text { Soma das atividades dos governos, que agem diretamente ou através de } \\
\text { delegação, e que influenciam a vida dos cidadãos. }\end{array}$ \\
Dye (1984) & O que o governo escolhe fazer ou não fazer. \\
Laswell (1958) & $\begin{array}{l}\text { Decisões e análises sobre política pública implicam responder às seguintes } \\
\text { questões: quem ganha o quê, por quê e que diferença faz. }\end{array}$ \\
\hline
\end{tabular}

Fonte: Elaborado pelos autores a partir de Souza (2007)

A autora pontua que o conceito mais conhecido é de Laswell e sintetiza a política pública como sendo:

O campo do conhecimento que busca, ao mesmo tempo, 'colocar o governo em ação' e/ou analisar essa ação (variável independente) e, quando necessário, propor mudanças no rumo ou curso dessas ações (variável dependente). A formulação de políticas públicas constitui-se no estágio em que os governos democráticos traduzem seus propósitos e plataformas eleitorais em programas e ações que produzirão resultados ou mudanças no mundo real (SOUZA, 2007, p. 26).

As políticas públicas distinguem-se em quatro tipos: políticas públicas distributivas, políticas públicas redistributivas, políticas públicas regulatórias e políticas públicas constitutivas. 
As políticas distributivas possuem baixo grau de processos políticos e buscam favorecer um grande percentual de destinatários, mas tem escala relativamente pequena. As políticas redistributivas são orientadas para o conflito e buscam alcançar grandes contingenciais sociais. Já as políticas regulatórias, os processos de conflitos irão depender conforme a configuração específica das políticas, porque trabalham com as ordens e proibições, decretos e portarias. E as políticas constitutivas vão determinar as condições gerais que as políticas distributivas, redistributivas e regulatórias serão negociadas, os procedimentos para que essas políticas entrem em vigor (FREY, 2000).

Assim, as políticas públicas podem possuir diversos objetivos e diferentes características e formatos, além do ciclo pelas quais percorre até chegar à sociedade.

Frey (2000) propõe a seguinte ordem sequencial para guiar o processo políticoadministrativo:

- Percepção e Definição de Problemas: nessa fase observa-se a existência de várias demandas políticas e a questão é que dentre essas várias opções, uma demanda específica se torna um problema público e irá gerar o ciclo da política.

- Agenda Setting: fase em que se define se um tema será inserido, excluído ou adiado da pauta política.

- Elaboração de Programas e de Decisão: nessa fase escolhe dentre as diversas alternativas de ação a mais apropriada para resolver o problema.

- Implantação de Políticas: fase que corresponde à concretização da alternativa escolhida, produzindo determinados resultados e impactos na política.

- Avaliação de Políticas e Correção da Ação: nessa fase avaliam-se os impactos efetivos e efeitos colaterais indesejados com o intuito de contornar as falhas em ações e programas futuros.

A forma de resolução de um problema político consiste numa sequência de passos, conforme o modelo de ciclos políticos, no entanto, os atores políticoadministrativos dificilmente se atêm a essa ordem na prática (FREY, 2000). Os problemas colocados na agenda das políticas públicas podem ser referentes a políticas setoriais para o melhor desenvolvimento e efetividade das políticas.

Nesse sentido, tem-se a política econômica de emprego, trabalho e renda. Um estudo do Instituto de Pesquisa Econômica Aplicada (2006) sintetiza a situação no que compete às políticas operantes nesse setor específico, a partir do Ministério do Trabalho e Emprego (Quadro 2).

Dentre as políticas públicas de emprego, trabalho e renda, está a economia solidária que foi introduzida no ano de 2003 na agenda pública do Brasil. Segundo o Plano Nacional de Economia Solidária, insere-se a economia solidária como política pública de governo com a perspectiva de se caracterizar como uma estratégia de desenvolvimento, alternativo ao modo de produção capitalista (BRASIL-SENAES, 2015). 
p. 53 - Políticas Públicas de Economia Solidária: uma Revisão da Literatura

Quadro 2: Principais Programas Federais de Emprego, Trabalho e Renda Operantes.

\begin{tabular}{|c|c|c|}
\hline \multicolumn{3}{|c|}{ Principais Programas Federais de Emprego, Trabalho e Renda Operantes } \\
\hline Nome & Descrição & Ano de Início \\
\hline Abono Salarial & $\begin{array}{l}\text { Benefício no valor de } 1 \mathrm{SM} \text { anual, assegurado aos } \\
\text { empregados que percebem até } 2 \mathrm{SMs} \text { de remuneração } \\
\text { mensal, desde que cadastrados há cinco anos ou mais no } \\
\text { PIS/Pasep e que tenham trabalhado pelo menos } 30 \text { dias } \\
\text { em um emprego formal no ano anterior. }\end{array}$ & $\begin{array}{l}1989 \text { (1970 para } \\
\text { contas individuais) }\end{array}$ \\
\hline $\begin{array}{l}\text { Intermediação } \\
\text { de mão-de- } \\
\text { obra/Sine }\end{array}$ & $\begin{array}{l}\text { Captação de vagas junto a empresas e encaminhamento } \\
\text { de trabalhadores em busca de emprego. }\end{array}$ & 1977 \\
\hline $\begin{array}{c}\text { Seguro- } \\
\text { desemprego }\end{array}$ & $\begin{array}{l}\text { Assistência financeira temporária ao trabalhador } \\
\text { desempregado, em virtude da dispensa sem justa causa. } \\
\text { Concedido em parcelas mensais, que variam de três a } \\
\text { cinco, dependendo do número de meses trabalhados nos } \\
\text { últimos } 36 \text { meses, para um período aquisitivo de } 16 \\
\text { meses. }\end{array}$ & $\begin{array}{l}\text { 1986: trabalhador } \\
\text { formal } \\
\text { 1992: pescador } \\
\text { artesanal } \\
\text { 2001: trabalhador } \\
\text { doméstico } \\
\text { 2003: trabalhador } \\
\text { resgatado }\end{array}$ \\
\hline $\begin{array}{l}\text { Qualificação } \\
\text { Profissional }\end{array}$ & $\begin{array}{l}\text { Oferta de cursos de qualificação profissional para } \\
\text { trabalhadores desempregados ou em risco de } \\
\text { desemprego e para microempreendedores. }\end{array}$ & 1995 \\
\hline $\begin{array}{l}\text { Geração de } \\
\text { Emprego e } \\
\text { Renda }\end{array}$ & $\begin{array}{l}\text { Concessão de crédito produtivo assistido a micro e } \\
\text { pequenas empresas, cooperativas e trabalhadores } \\
\text { autônomos. }\end{array}$ & 1995 \\
\hline $\begin{array}{l}\text { Primeiro } \\
\text { Emprego para a } \\
\text { Juventude }\end{array}$ & $\begin{array}{l}\text { Promoção do ingresso do jovem no mundo do trabalho } \\
\text { por meio de qualificação profissional, estímulo financeiro } \\
\text { às empresas contratantes, parcerias para contratação de } \\
\text { aprendizes e apoio à constituição de empreendimentos } \\
\text { coletivos pelos jovens. }\end{array}$ & 2003 \\
\hline $\begin{array}{l}\text { Economia } \\
\text { Solidária }\end{array}$ & $\begin{array}{l}\text { Apoio à formação e divulgação de redes de } \\
\text { empreendimentos solidários pelo fomento direto, } \\
\text { mapeamento das experiências e constituição de } \\
\text { incubadoras. }\end{array}$ & 2003 \\
\hline
\end{tabular}

Fonte: Adaptado pelos autores a partir de BRASIL-IPEA (2006)

\section{ECONOMIA SOLIDÁRIA COMO ESTRATÉGIA DE DESENVOLVIMENTO}

A economia solidária é um projeto de sociedade que busca uma nova forma de organização econômica como estratégia de enfrentamento ao desemprego e à exclusão social. Segundo Gaiger (2003) a economia solidária rompe com as relações de produção capitalistas, introduzindo experiências populares pautadas em fundamentos de cooperação econômica e autogestão.

A competição gera sociedades fortemente desiguais e para que houvesse uma sociedade em que prevalecesse uma maior igualdade, seria necessário que a economia fosse solidária. Dessa forma, os membros da atividade econômica deveriam cooperar entre si. Assim, os que se associam para produzir, comerciar, consumir ou poupar se organizam de forma igualitária. Todos os sócios possuem igual parcela do capital e o 
mesmo direito de voto na tomada de decisão, e se a empresa progredir, acumular dividendos, todos ganham de forma equânime, e da mesma forma se houver dívidas e prejuízos, todos participam com igualdade para saldar os débitos (SINGER, 2002). A cooperação econômica é fundamental para esse tipo de economia que tem como princípio de propriedade coletiva e o direito de liberdade individual.

Outra característica fundamental da economia solidária é a autogestão. Sobre esse aspecto Singer (2002) aponta como a diferença principal entre uma economia capitalista e uma solidária, que corresponde à forma como as empresas são administradas. Aplica-se a heterogestão, na economia capitalista, que significa uma gestão hierárquica em que as informações são de baixo para cima e as ordens de cima para baixo, possuindo níveis sucessivos de autoridade. Na autogestão, característica das empresas socioeconômicas, a administração é democrática. A autogestão exige maior esforço dos trabalhadores da empresa que além das tarefas habituais devem se ocupar dos problemas gerais da organização e para isso é necessário que todos os sócios tenham conhecimento do que acontece e das alternativas possíveis para tomar decisões.

Essa nova forma econômica projeta consigo fundamentos de coletividade e solidariedade que são importantes para o cenário de grandes desigualdades sociais, no entanto, possuem desafios a serem enfrentados para que continue e cresça esse movimento.

Um estudo feito por Addor (2006) apresenta, de forma sistematizada, os principais desafios da economia solidária no Brasil:

- Estruturação da Comercialização: há inúmeras variáveis que influenciam na compra e venda de produtos de empreendimentos de economia solidária. Para a maior sustentação e desenvolvimento, um desafio a ser superado é construção vínculos para formar um mercado solidário, no qual os integrantes da rede criada buscariam comercializar produtos entre si. Além de buscar a formação de arranjos produtos para propiciar o desenvolvimento local por meio da economia solidária. O segundo desafio é o problema de obtenção de crédito, porque não há no Brasil uma política de crédito para empreendimento de economia solidária. O terceiro desafio nessa área de comercialização é a conquista de consumidores, para que opte por produtos de organizações solidárias de forma prioritária. E um último ponto, é a dificuldade de atuação em nível global desses empreendimentos e é importante que estes superem o alcance local.

- Manutenção da Consistência Ideológica: preocupa-se com a fidelidade aos fundamentos da economia solidária. À medida que se estabiliza e se consolida o empreendimento o aspecto ideológico pode ser ameaçado, acumula-se capital que pode gerar ambições individualistas dentro do grupo. Da mesma forma, à medida que a empresa cresce, as decisões passam a ter maior complexidade e urgência o que pode trazer conflitos para a forma horizontal de gerenciar essas organizações. Outra questão é a contratação de empregados que fere os conceitos da economia solidária e tem sido presente no cooperativismo brasileiro. Com isso é um desafio substancial o consenso quanto à consistência ideológica da economia solidária para sua consolidação. 
p. 55 - Políticas Públicas de Economia Solidária: uma Revisão da Literatura

- Contribuição Técnico-científica: nesse desafio há dois problemas cernes, a formação dos trabalhos e a contribuição dos acadêmicos. A autogestão, característica da economia solidária, exige a formação de todos os envolvidos no empreendimento, uma vez que além de ser necessário conhecimento na parte técnica, irá demandar conhecimento administrativo. Nesse sentido, a comunidade acadêmica é importante para além de transmitir conhecimentos já preconcebidos, desenvolver técnicas de gerenciamento de empresas de autogestão que são específicas e divergentes de empresas capitalistas. E após o desenvolvimento de novos conhecimentos, formular metodologias de ensino para o público-alvo em questão.

- Organização de Políticas Públicas: o desafio é incluir a economia solidária dentro do programa de desenvolvimento nacional, assim empreendimentos socioeconômicos seriam considerados na articulação de todas as políticas governamentais, sendo um vetor para o desenvolvimento. O governo, por meio das leis, deve contribuir para a sustentabilidade desse movimento, mantendo o cuidado de não tornar o vínculo forte, e assim, ameaçar a sobrevivência da economia solidária em mudanças governamentais.

Os desafios são diversos, no entanto, a economia solidária pode ser uma opção possível de "enfrentamento do processo de exclusão social, econômico e político, inclusive no combate à precarização das relações de trabalho, das condições de trabalho e vida, podendo representar os embriões da geração de uma nova estratégia política de desenvolvimento" (SILVA, 2010, p. 147).

Na superação desses desafios e no fomento da economia solidária como uma estratégia alternativa de desenvolvimento, as políticas públicas de economia solidária têm papel fundamental e contribuem de forma considerável, o que será tratado a seguir.

\section{POLÍTICAS PÚBLICAS DE ECONOMIA SOLIDÁRIA}

As políticas públicas de fomento da economia solidária têm papel significativo no apoio, desenvolvimento e fortalecimento desses empreendimentos solidários.

Para Singer (2006, p. 205) as políticas públicas "são decisivas para ajudar os mais pobres a se auto-organizar, para coletivamente desenvolverem trabalho e obterem renda, uma vez que só fundos públicos têm capacidade para estender o avanço da economia solidária aos que mais carecem dela".

As políticas públicas de economia solidária já atingiram as três esferas governamentais, o que demonstra sua relevância no contexto do país, e tem progredido na sua organização política, criando fóruns e redes para superar inciativas isoladas e fragmentadas (SILVA, 2009; SILVA, 2011).

As articulações ganharam impulso, no final da década de 90, e se consolidaram com a criação do Grupo de Trabalho Brasileiro de Economia Solidária, no ano 2001, nos Fóruns Sociais Mundiais realizados no Brasil. Em 2002, foi realizada a Primeira Plenária Brasileira de Economia Solidária, com a elaboração de 
uma Plataforma Nacional de Economia Solidária. No ano seguinte, foi criada a Secretaria Nacional de Economia Solidária (SENAES) no âmbito do Ministério do Trabalho e Emprego (MTE), fruto do esforço político conjunto de uma série de organizações, que atua na economia solidária. No mesmo período, em junho de 2003, realizou-se a Terceira Plenária Nacional de Economia Solidária, criando o Fórum Brasileiro de Economia Solidária (SILVA, 2011, p. 10).

Além disso, existem fóruns estaduais, territoriais e municipais que tem como participantes empreendimentos, entidades de apoio, e rede de gestores públicos de economia solidária. Foram criadas novas organizações como a União das Cooperativas de Economia Solidária (UNICAFES) e a União e Solidariedade de Cooperativas e Empreendimentos de Economia Social (UNISOL). Foram realizados, também, encontros para tratar do tema, como o I Encontro Nacional de Empreendimentos Econômicos Solidários (SILVA, 2011).

A Secretaria Nacional de Economia Solidária (SENAES) é considerada a grande propulsora da expansão a nível nacional da economia solidária. O objetivo da secretaria é "viabilizar e coordenar atividades de apoio à Economia Solidária em todo o território nacional, visando à geração de trabalho e renda, à inclusão social e à promoção do desenvolvimento justo e solidário" (BRASIL-SENAES, 2003, p.1).

Dessa forma, a política pública de empreendimentos de economia solidária é executada pela SENAES por meio de repasse de recursos a estados, municípios, universidades e organizações da sociedade civil que articulam projetos para apoiar e estimular o crescimento da economia solidária. Diversas ações são desenvolvidas pela SENAES, conforme exemplifica o quadro 3 (BRASIL-MTE, 2016):

Quadro 3: Ações da SENAES para Fomento da Economia Solidária.

\begin{tabular}{|l|}
\hline \multicolumn{1}{|c|}{ Ações da SENAES para Fomento da Economia Solidária } \\
\hline Programa de Desenvolvimento Regional, Territorial Sustentável e Economia Solidária (PPA 2012/2015) \\
Programa Nacional de Associativismo e Cooperativismo Social (Pronacoop Social) \\
Programa Nacional de Incubadoras de Cooperativas Populares (PRONINC) \\
\hline Programa de Resíduos Sólidos (PPA 2012-2015) \\
Ações Integradas \\
Catadores e Catadoras \\
Associativismo e Cooperativismo Social \\
Comércio Justo e Solidário \\
Finanças Solidárias \\
Formação \\
Incubação, Pesquisa e Extensão \\
Informações \\
Redes de Cooperação Solidária
\end{tabular}

Fonte: Adaptado pelos autores a partir de BRASIL-MTE (2016) 
p. 57 - Políticas Públicas de Economia Solidária: uma Revisão da Literatura

As ações da SENAES tiveram impacto considerável para o incentivo a economia solidária, conforme se pode constatar na tabela 1 que representa o orçamento executado pela secretaria e o número de beneficiários entre 2003 e 2009.

Tabela 1: Orçamento Executado pela SENAES/MTE e Número de Beneficiários.

\begin{tabular}{|ccc|}
\hline ANO & ORÇAMENTO EXECUTADO & No BENEFICIÁRIOS \\
\hline 2003 & $\mathrm{R} \$ 476.089,00$ & 611 \\
\hline 2004 & $\mathrm{R} \$ 18.654 .312,00$ & 44.600 \\
2005 & $\mathrm{R} \$ 12.411 .376,00$ & 24.300 \\
2006 & $\mathrm{R} \$ 14.251 .666,00$ & 27.300 \\
2007 & $\mathrm{R} \$ 46.963 .497,00$ & 89.750 \\
2008 & $\mathrm{R} \$ 21.449 .584,00$ & 56.139 \\
2009 & $\mathrm{R} \$ 49.140 .140,60$ & 115.284 \\
\hline TOTAL & $163.396 .664,60$ & 357.984 \\
\hline
\end{tabular}

Fonte: Adaptado pelos autores a partir de SENAES/MTE, 2010 apud SILVA, 2011.

Conquistaram-se importantes espaços e ampliou parcerias para fortalecer a economia solidária, no entanto, os empreendimentos socioeconômicos ainda carecem de mais políticas públicas para sua consolidação, requer-se maior responsabilização pública estruturando o setor e proporcionando amparo aos trabalhadores, o que retrata a complexa tarefa de dar sustentabilidade e longevidade a essas iniciativas (SILVA, 2011; BARBOSA, 2007).

\section{METODOLOGIA}

O presente estudo tem o objetivo de realizar uma revisão de literatura da produção de estudos científicos sobre políticas públicas de economia solidária a fim de verificar quais as políticas públicas foram criadas no âmbito federal, estadual e municipal para fomentar a Economia Solidária.

Para isso, realizou-se um levantamento bibliográfico com a finalidade exploratória e descritiva, considerando a abordagem qualitativa com a exposição dos estudos analisados. Após a seleção dos artigos, realizou-se o estudo pormenorizado dos mesmos, a fim de identificar se havia menção de alguma política pública diretamente relacionada com o movimento de economia solidária. E, se sim, aspectos mais específicos eram investigados, como, autor e ano de realização da pesquisa, a esfera pública da política, nome dado e breve descrição do programa governamental, para assim, destacar a relevância da política pública de economia solidária para a estratégia de desenvolvimento e fortalecimento desse tipo de economia.

\section{RESULTADOS E DISCUSSÕES}

Os vários estudos considerados trouxeram como resultados a articulação das diversas esferas de governo para promover, apoiar e fortalecer a economia solidária por meio de políticas públicas. Foram levantados 61 programas para o desenvolvimento da 
Economia Solidária, sendo que a maior parte deles está na escala municipal, seguido pelos programas federais, como pode ser observado no gráfico 1:

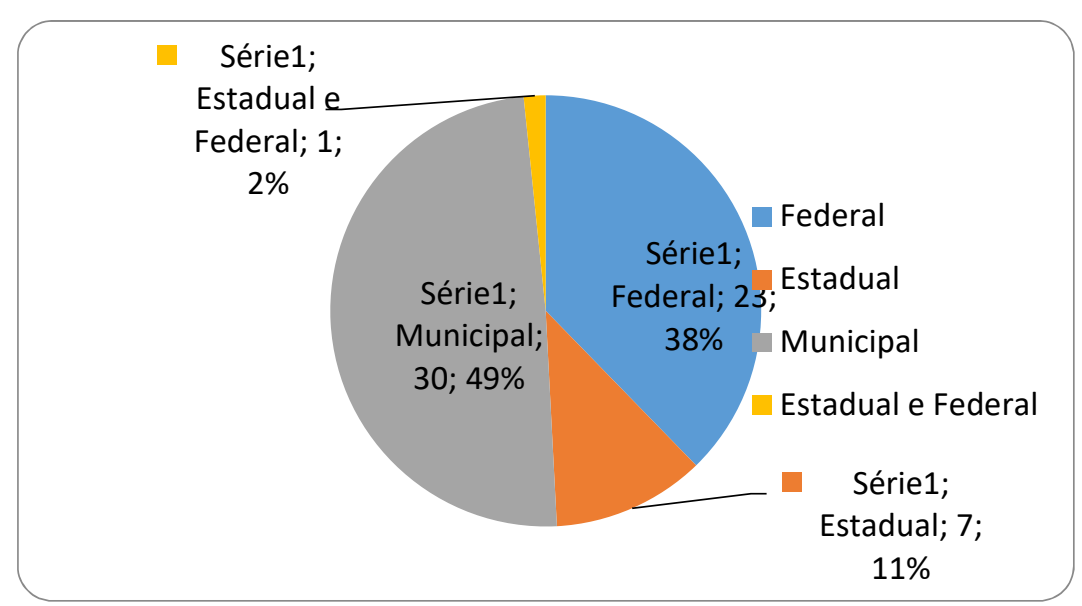

Gráfico 1 - Número de Programas Governamentais de Fomento à Economia Solidária de acordo com as esferas governamentais

Fonte: Elaborado pelos autores a partir do levantamento bibliográfico.

Constata-se com a pesquisa que as políticas públicas voltadas para a economia solidária atingiram as três esferas governamentais (federal, estadual e municipal), o que corrobora para o entendimento que esse movimento tem crescido e mostrado sua relevância nas políticas sociais do país ${ }^{1}$.

Dentre os estudos que houve menção de algum programa de política pública diretamente relacionado com a economia solidária, destaca-se, no âmbito federal, o Programa Economia Solidária em Desenvolvimento, citado por 7 autores, e também, o Programa Nacional de Incubadoras de Cooperativas Populares (Proninc), que foi citado por 6 autores.

O governo federal, em 2003, tornou a Economia Solidária como política integrante da agenda pública, com a criação da Secretaria Nacional de Economia Solidária (SENAES) que foi inserida na estrutura do Ministério do Trabalho e Emprego (MTE). O Programa Economia Solidária em Desenvolvimento, de acordo com Nagem (2011), tem sete eixos de ação: fomento, comercialização, sistema de informação em Economia Solidária, institucionalização de políticas públicas governamentais, apoio, assistência técnica, e contratação, capacitação e formação. Para alcançar esses objetivos, as ações foram contempladas em dois Planos Plurianais (PPAs): o de 2004-2007 e o de 2008-2011.

O outro programa de destaque a nível federal atinge as Incubadoras de Cooperativas Populares que utiliza "os recursos humanos e conhecimento da universidade na formação, qualificação e assessoria de trabalhadores para a construção

\footnotetext{
1 - O Apêndice 1 apresenta um quadro com o panorama completo dos resultados obtidos com a pesquisa realizada.
} 
de atividades autogestionárias, visando sua inclusão no mercado de trabalho" (GUIMARÃES, 2003, p. 111). Nesse programa, as universidades com projetos de ensino, pesquisa e extensão com a incubação de empreendimentos, tem contribuído de forma significativa para o fomento e fortalecimento da economia solidária.

Dentro dessa política de incentivo, por meio de incubadoras, o estudo de Monteiro (2009), Praxedes (2009) e Cunha (2002) chama a atenção para um avanço nas políticas públicas mostrando que foram criadas incubadoras para incentivar a Economia Popular e Solidária, mas agora, no domínio de prefeituras municipais, já que até então, no Brasil, existiam iniciativas ligadas apenas às universidades e ao terceiro setor. A exemplo tem-se as incubadoras de Paulista-PE, Santo André-SP, Osasco-SP, Mesquita-RJ e as do estado da Bahia. Praxedes (2009, p. 4) afirma que "essas experiências demonstraram a necessidade de ações concretas do ponto de vista da gestão pública".

Na esfera estadual, ressalta-se o Programa de Economia Popular Solidária (ECOPOPSOL) do governo do estado do Rio Grande do Sul, desenvolvido na gestão entre os anos de 1998 e 2002. O programa foi pioneiro de abrangência estadual e institucionalizado pelo Decreto № 41.062, de 21 de Setembro de 2001. De acordo com esse decreto (BRASIL, 2001) a ação política tem como eixos: formação e educação em autogestão; capacitação do processo produtivo; financiamento; comercialização e incubadoras de economia popular solidária. Segundo o estudo de Silva (2009), foram formados e apoiados mais de 180 empreendimentos de economia solidária, os resultados foram considerados significativos, e apesar das ações estarem mais concentradas na região metropolitana de Porto Alegre, o programa conseguiu refletir de forma descentralizada e diversificada por todo o estado.

Nos programas de nível municipal é oportuno mencionar o estudo de Benini (2004) que trouxe 19 programas municipais de fomento a economia solidária, mostrando a diversidade dos programas, a capacidade de um local explorar suas potencialidades e a pulverização das ações públicas em prol desse tipo de economia.

Ressalta-se, também, o programa Oportunidade Solidária de São Paulo, implantado no período entre 2001-2004, que foi o mais citado no âmbito municipal, talvez pela relevância do programa e desafio de acontecer na principal cidade do país. De acordo com o estudo de Gomes e Alves (2005), o programa objetiva combater a exclusão por meio da criação de cooperativas populares, na pesquisa desses autores, constataramse algumas fragilidades do programa, como em relação ao repasse dos recursos financeiros e na retenção dos beneficiários, no entanto, observam-se também avanços, na oportunidade de retorno aos estudos dos cooperados e do programa ter alcançado à população mais carente da cidade, criando uma relação do poder público com essa parcela da população.

Verifica-se com esta pesquisa que a economia solidária vem obtendo apoio crescente dos governos, e as políticas públicas tem se ampliado significativamente, em âmbito federal, estadual e municipal, com o estabelecimento de programas e ações de apoio.

Essa política de apoio a economia solidária apresenta uma nova concepção de políticas públicas de geração de trabalho e renda no Brasil, ao fomentar a formação de 
empreendimentos coletivos e promover a capacitação técnica e produtiva dos membros, busca-se um desenvolvimento que não é pautado apenas no princípio capitalista e se estabelece novas tendências na relação entre Estado e sociedade (NATIVIDADE; PEREIRA; OLIVEIRA, 2011).

Esses avanços na concepção de políticas públicas são fundamentais para o desenvolvimento e esta pesquisa reflete o potencial investigativo e a riqueza da análise das políticas públicas em prol do desenvolvimento estratégico da economia solidária em todos os domínios da federação.

\section{CONSIDERAÇÕES FINAIS}

O presente estudo propôs como objetivo geral realizar uma revisão de literatura da produção de estudos científicos sobre políticas públicas de economia solidária a fim de verificar quais as políticas públicas foram criadas no âmbito federal, estadual e municipal para fomentar a Economia Solidária.

Dessa forma, para atingir tal objetivo, realizou-se uma pesquisa bibliográfica, identificando as ações de políticas públicas de economia solidária nas diversas esferas do governo. Destaca-se a nível federal o Programa Economia Solidária em Desenvolvimento e o Programa Incubadoras de Cooperativas Populares. Em esfera estadual ressalta-se o Programa de Economia Popular Solidária do governo do estado do Rio Grande do Sul, e em esfera municipal, o Programa Oportunidade Solidária do município de São Paulo.

A contribuição desta pesquisa para o poder público consiste em evidenciar a diversidade dos programas existentes em favor da economia solidária para que possam potencializar e disseminar o desenvolvimento desse tipo de economia. Sugere-se para pesquisas futuras, um estudo abrangendo ações de políticas públicas distintas que podem estar dentro da conjuntura mais ampla da economia solidária, mas que não foram concebidos diretamente no contexto do movimento, devido ao caráter de transversalidade que essa política pública possui nas ações governamentais.

\section{REFERÊNCIAS BIBLIOGRÁFICAS}

ADDOR, Felipe. Desafio da Economia Solidária no Brasil: uma sistematização da literatura existente. Artigo acadêmico. 12 f. SOLTEC/UFRJ, Rio de Janeiro, 2006.

ALANIZ, Erika Porceli. A Política Pública de Formação para Economia Solidária no Brasil (2003-2011): análise de um projeto PROESQ/PNQ executado pela Rede Abelha/RN e CFES nacional. Tese - Faculdade de Educação, USP, São Paulo, 2012, 370 p.

ARAÚJO, Herton Ellery; SILVA, Frederico A. Barbosa da Silva. Economia Solidária: um novo paradigma de política pública?. IPEA, 2005, 9 p.

BARBOSA, Rosangela Nair de Carvalho. A Economia Solidária como Política Pública: uma Tendência de Geração de Renda e Ressignificação do Trabalho no Brasil. São Paulo: Cortez, 2007. 
p. 61 - Políticas Públicas de Economia Solidária: uma Revisão da Literatura

BENINI, Edi A. et al. Gestão Pública e Sociedades: fundamentos e políticas de economia solidária. São Paulo: Outras Expressões, v. 1, 1 ed., 2011, 480 p.

BENINI, Edi Augusto. Políticas Públicas e Relações de Trabalho: estudo sobre o processo e natureza da denominada "Economia Solidária", enquanto política pública, a partir da investigação de alguns casos concretos. Dissertação - Escola de Administração de Empresas, FGV, São Paulo, 2004, 118 p.

BITELMAN, Marina Farkas. A Disseminação das Políticas Públicas Locais de Economia Solidária no Brasil: Os casos de São Paulo e Osasco. Dissertação - Escola de Administração de Empresas, FGV, São Paulo, 2008, 190 p.

BRASIL. Decreto no 41.062, de 21 de setembro de 2001. Institui o Programa de Economia Popular Solidária e dá outras providências. Palácio Piratini, em Porto Alegre, 21 set 2001.

BRASIL. Instituto de Pesquisa Econômica Aplicada. Brasil: o estado de uma nação mercado de trabalho, emprego e informalidade, 2006/Paulo Tafner, editor. Rio de Janeiro: IPEA, 2006.

BRASIL. Ministério do Trabalho e Emprego. Economia Solidária. Brasília: Ministério do Trabalho e Emprego, 2015. Disponível em: < http://trabalho.gov.br/trabalhadoreconomia-solidaria/o-que-e>. Acesso em: 12/10/2016.

BRASIL. Ministério do Trabalho e Emprego. Programas e Ações. Brasília: Ministério do Trabalho e Emprego, 2016. Disponível em: < http://trabalho.gov.br/trabalhadoreconomia-solidaria/programas-e-acoes $>$. Acesso em: 14/10/2016.

BRASIL. Secretaria Nacional de Economia Solidária. Secretaria Nacional de Economia Solidária - SENAES/MTE. Disponível em:

<http://www.economiaviva.com.br/?q=node/163>. Acesso em: 14/10/2016.

BRASIL. Secretaria Nacional de Economia Solidária. Secretaria Nacional de Economia Solidária - SENAES/MTE. Disponível em: <

http://trabalho.gov.br/images/Documentos/EconomiaSolidaria/PlanoNacionalEcoSol.pd $f>$. Acesso em: 14/10/2016.

CUNHA, Gabriela Cavalcanti. Economia Solidária e Políticas Públicas: reflexões a partir do caso do programa Incubadora de Cooperativas, da Prefeitura Municipal de Santo André - SP. Dissertação - Faculdade de Filosofia, Letras e Ciências Humanas, USP, São Paulo, $171 \mathrm{p}$.

FREY, Klaus. Políticas Públicas: Um Debate Conceitual e Reflexões Referentes à Prática da Análise de Políticas Públicas no Brasil. Planejamento e Políticas Públicas, no 21, jun. 2000.

GAIGER, Luiz Inácio Germany. A Economia Solidária Diante do Modo de Produção Capitalista. Caderno CRH, Salvador, n. 39, p. 181-211, jul./dez. 2003.

GOMES, V. P. G.; ALVES, M. O Programa Oportunidade Solidária e a emancipação: uma visão crítica. In: Encontro Internacional de Economia Solidária. 4., São Paulo, 2005. Anais... São Paulo: USP, 2005. 
GUIMARÃES, G. Incubadoras de Cooperativas Populares: contribuição para um modelo alternativo de geração de trabalho e renda. In: SINGER, P.; SOUZA, A. R. (Orgs) A economia solidária no Brasil: a autogestão como resposta ao desemprego. São Paulo: Contexto, 2003.

GUTIERREZI, Gustavo Luis. Economia Solidária: de movimento político a política de Estado. ORG \& DEMO, v. 5, n. 1, p. 9-22, 2004.

hOCHMAN, G.; ARRETCHE, M.; MARQUES, E., orgs. Políticas Públicas no Brasil [online]. Rio de Janeiro: Editora FIOCRUZ, 2007. 398p. ISBN 978-85-7541-350-0. Available from SciELO Books <http://books.scielo.org>.

LIMA, Jacob Carlos. Economia Solidária: de movimento social a política pública. UFSC, 2015, 27 p.

MELO, Creusa da Silva. Política Pública de Economia Solidária no Brasil? Avaliação política dos seus fundamentos ideológicos. Dissertação - Centro de Ciências Sociais Aplicadas, UFPE, Recife, 2012, 138 p.

MONTEIRO, Péricles Cerqueira. A Economia Solidária como Política Pública: Desafios de uma construção - reflexões a partir da experiência Baiana. Dissertação - Escola de Administração, UFB, Bahia, 2009, 154 p.

NAGEM, Fernanda Abreu. Os Caminhos do Programa Economia Solidária em Desenvolvimento. Viçosa, 2011.

NATIVIDADE, Elisângela Abreu; PEREIRA, José Roberto; OLIVEIRA, Vânia Aparecida Rezende de. Gestão Social de Políticas Públicas de Geração de Trabalho e Renda: uma reflexão por meio das ações da Secretaria Nacional de Economia Solidária. APGS, Viçosa, v. 3, n. 1, p. 1-22, jan./mar. 2011.

NEVES, Ednalva Felix das. Economia Solidária: alternativa ao sistema capitalista. Disponível em: < http://brasildebate.com.br/economia-solidaria-alternativa-ao-sistemacapitalista/>. Acesso em: 12/10/2016.

PAMPLONA, Leonardo. Políticas Públicas de Geração de Trabalho e Renda: o desafio da atuação do BNDES na Economia Solidária. BNDES Setorial, Rio de Janeiro, n. 30, p. 63102, 2009.

PERES, Géssica; MARTINS, Leila Andrésia Severo. Construção e Fomento de Políticas Públicas em Economia Solidária: a organização do Fórum Litorâneo de Economia Solidária. RAI. RUM., vol. 02, n. 01, Rio de Janeiro, Jun. 2014, 14 p.

PRAXEDES, Sandra Faé. Políticas Públicas de Economia Solidária: novas práticas, novas metodologias. IPEA, 2009, $6 \mathrm{p}$.

SILVA, Andréia Vieira da. Economia Solidária: uma estratégia política de desenvolvimento. Tese - Centro de Ciências Humanas, Letras e Artes, UFPB, João Pessoa, 2010, 208 p.

SILVA, Sandro Pereira. Economia Solidária e Políticas Públicas de Desenvolvimento Local: Uma Análise de Dois Programas de Gestão Pública no Brasil. Perspectivas em Políticas Públicas, Belo Horizonte, v. II, n. 3, p. 45-67, jan./jun. 2009. 
p. 63 - Políticas Públicas de Economia Solidária: uma Revisão da Literatura

SILVA, Sandro Pereira; NAGEM, Fernanda Abreu. A Economia Solidária na Agenda das Políticas Públicas Nacionais: uma análise do programa Economia Solidária em desenvolvimento. IPEA, Brasília, 2011, 40 p.

SILVA, Roberto Marinho Alves da. Políticas Públicas de Economia Solidária: Avanços, Desafios e Perspectivas. Diálogo, Canoas, n. 18, p. 53-76, jan./jun. 2011.

SINGER, Paul. Introdução à Economia Solidária. 1a ed. São Paulo: Editora Fundação Perseu Abramo, 2002.

SINGER, Paul. Políticas Públicas da Secretaria Nacional de Economia Solidária do Ministério do Trabalho e Emprego. IPEA, 2009, 6 p.

SINGER, Paul. SENAES: uma experiência brasileira de política de economia solidária. In: FRANÇA FILHO, G. C.; LAVILLE, J.; MEDEIROS, A.; MAGNEN, J. Ação pública e economia solidária: uma perspectiva internacional. Porto Alegre: UFRGS, p. 201-206, 2006.

SOUZA, Celina. Políticas Públicas: uma revisão de literatura. Sociologias, Porto Alegre, ano 8, n. 16,. 20-45, jul./dez. 2006. 


\section{Apêndice 1}

\section{Programas Governamentais de Fomento à Economia Solidária no Brasil}

\begin{tabular}{|c|c|c|c|c|}
\hline $\begin{array}{l}\text { Esfera } \\
\text { Política }\end{array}$ & Nome Programa & Descrição do Programa & $\begin{array}{l}\text { Autor(es) do } \\
\text { Estudo } \\
\text { Científico }\end{array}$ & $\begin{array}{c}\text { Ano } \\
\text { Publicação }\end{array}$ \\
\hline Federal & $\begin{array}{l}\text { Programa } \\
\text { Economia } \\
\text { Solidária em } \\
\text { Desenvolvimento }\end{array}$ & $\begin{array}{l}\text { Política de Formação em Economia Solidária, Mapeamento } \\
\text { Nacional da Economia Solidária, Brasil Local e Programa } \\
\text { Nacional de Incubadoras de Cooperativas Populares. }\end{array}$ & $\begin{array}{l}\text { Elisângela } \\
\text { Abreu } \\
\text { Natividade e } \\
\text { José Roberto } \\
\text { Pereira } \\
\end{array}$ & 2011 \\
\hline Federal & $\begin{array}{l}\text { Política de } \\
\text { Formação em } \\
\text { Economia } \\
\text { Solidária }\end{array}$ & $\begin{array}{l}\text { Política de Formação em Economia Solidária tem o intuito de } \\
\text { proporcionar cursos de economia solidária aos servidores } \\
\text { dos três níveis de governo. Capacitaram-se } 4300 \\
\text { trabalhadores e } 800 \text { educadores em nove redes de } \\
\text { cooperação desse tipo de economia, em } 2007 \text { e } 2008 \text {. }\end{array}$ & $\begin{array}{l}\text { Elisângela } \\
\text { Abreu } \\
\text { Natividade e } \\
\text { José Roberto } \\
\text { Pereira } \\
\end{array}$ & 2011 \\
\hline Federal & $\begin{array}{l}\text { Mapeamento } \\
\text { Nacional da } \\
\text { Economia } \\
\text { Solidária }\end{array}$ & $\begin{array}{l}\text { A realidade da economia solidária foi mapeada para fornecer } \\
\text { informações que servem de subsídio orientar as ações de } \\
\text { fomento da economia solidária. Em 2007, o "Atlas da } \\
\text { Economia Solidária" foi desenvolvido e mostrou que no Brasil } \\
\text { existia } 22 \text { mil empreendimentos econômicos, } \\
\text { compreendendo cerca de } 1,7 \text { milhão de associados e que } \\
\text { movimentavam, anualmente, cerca de } R \$ 6 \text { bilhões. }\end{array}$ & $\begin{array}{l}\text { Elisângela } \\
\text { Abreu } \\
\text { Natividade e } \\
\text { José Roberto } \\
\text { Pereira }\end{array}$ & 2011 \\
\hline Federal & Brasil Local & $\begin{array}{l}\text { Busca o desenvolvimento por meio de agentes solidários em } \\
\text { comunidades pobres. Entre os anos de } 2005 \text { e } 2008 \text {, foram } \\
\text { auxiliados } 700 \text { empreendimentos de economia solidária, dos } \\
\text { quais participaram } 45 \text { mil trabalhadores do país. }\end{array}$ & $\begin{array}{l}\text { Elisângela } \\
\text { Abreu } \\
\text { Natividade e } \\
\text { José Roberto } \\
\text { Pereira }\end{array}$ & 2011 \\
\hline Federal & $\begin{array}{c}\text { Programa } \\
\text { Nacional de } \\
\text { Incubadoras de } \\
\text { Cooperativas } \\
\text { Populares }\end{array}$ & $\begin{array}{l}\text { Apoia e desenvolve as experiências de Incubadoras } \\
\text { Tecnológicas de Cooperativas Populares realizadas por } \\
\text { universidades brasileiras. Esse programa em } 2003 \text { ampliou } \\
\text { sua atuação, chegando a apoiar, aproximadamente, } 80 \\
\text { incubadoras. }\end{array}$ & $\begin{array}{l}\text { Elisângela } \\
\text { Abreu } \\
\text { Natividade e } \\
\text { José Roberto } \\
\text { Pereira }\end{array}$ & 2011 \\
\hline Federal & $\begin{array}{l}\text { Programa } \\
\text { Economia } \\
\text { Solidária em } \\
\text { Desenvolvimento }\end{array}$ & $\begin{array}{l}\text { O programa busca promover acesso a bens e serviços } \\
\text { financeiros, de infraestrutura, conhecimentos (formação, } \\
\text { assessoramento e assistência técnica) e organização de } \\
\text { processos de produção e comercialização para subsidiar as } \\
\text { principais demandas dos empreendimentos de economia } \\
\text { solidária. A Secretaria Nacional de Economia Solidária, entre } \\
2003 \text { e 2009, executou um orçamento de } R \$ 163,3 \text { milhões } \\
\text { e beneficiaram quase } 358 \text { mil trabalhadores. }\end{array}$ & $\begin{array}{l}\text { Roberto } \\
\text { Marinho Alves } \\
\text { da Silva }\end{array}$ & 2011 \\
\hline Federal & $\begin{array}{l}\text { Programa } \\
\text { Nacional de } \\
\text { Fomento às } \\
\text { Cooperativas de } \\
\text { Trabalho }\end{array}$ & $\begin{array}{l}\text { Atende às demandas das cooperativas da economia solidária } \\
\text { e incentivar o cooperativismo autentico na área de produção } \\
\text { e prestação de serviços, buscando combater a exploração e } \\
\text { precarização do trabalho em falsas cooperativas. }\end{array}$ & $\begin{array}{l}\text { Roberto } \\
\text { Marinho Alves } \\
\text { da Silva }\end{array}$ & 2011 \\
\hline Federal & $\begin{array}{l}\text { Programa } \\
\text { Nacional de } \\
\text { Microcrédito } \\
\text { Produtivo } \\
\text { Orientado }\end{array}$ & $\begin{array}{l}\text { Fortalecimento das instituições de microcrédito, como as } \\
\text { cooperativas de crédito solidário, para ampliar a modalidade } \\
\text { de financiamento de empreendimentos econômicos } \\
\text { solidários. Dentre as ações, visou-se estimular parcerias com } \\
\text { Bancos Públicos, para financiar empresas em regime de } \\
\text { autogestão e cooperativas de catadores de matérias } \\
\text { recicláveis. }\end{array}$ & $\begin{array}{l}\text { Roberto } \\
\text { Marinho Alves } \\
\text { da Silva }\end{array}$ & 2011 \\
\hline Federal & $\begin{array}{c}\text { Programa Brasil } \\
\text { Local }\end{array}$ & $\begin{array}{l}\text { Busca promover a formação de empreendimentos de } \\
\text { economia solidária, propiciando a geração de trabalho e } \\
\text { renda e desenvolvimento de práticas autogestionárias. } \\
\text { Capacitou-se, de } 2005 \text { a } 2010,1.500 \text { agentes comunitários e, } \\
\text { atualmente, } 600 \text { deles estão acompanhando centenas de } \\
\text { empreendimentos econômicos solidários nos } 27 \text { estados da } \\
\text { Federação. }\end{array}$ & $\begin{array}{l}\text { Roberto } \\
\text { Marinho Alves } \\
\text { da Silva }\end{array}$ & 2011 \\
\hline Federal & $\begin{array}{l}\text { Programa } \\
\text { Nacional de } \\
\text { Incubadoras de } \\
\text { Cooperativas } \\
\text { Populares }\end{array}$ & $\begin{array}{l}\text { Programa que possibilita atuar nas demandas dos } \\
\text { empreendimentos de economia solidária, transmitindo } \\
\text { conhecimentos e tecnologias sociais. Entre } 2003 \text { e 2010, a } \\
\text { esfera pública apoiou } 82 \text { incubadoras universitárias, } \\
\text { favorecendo diversos trabalhadores associados. }\end{array}$ & $\begin{array}{l}\text { Roberto } \\
\text { Marinho Alves } \\
\text { da Silva }\end{array}$ & 2011 \\
\hline
\end{tabular}




\section{p. 65 - Políticas Públicas de Economia Solidária: uma Revisão da Literatura}

\begin{tabular}{|c|c|c|c|c|}
\hline $\begin{array}{l}\text { Esfera } \\
\text { Política }\end{array}$ & Nome Programa & Descrição do Programa & $\begin{array}{l}\text { Autor(es) do } \\
\text { Estudo } \\
\text { Científico }\end{array}$ & $\begin{array}{c}\text { Ano } \\
\text { Publicação }\end{array}$ \\
\hline Federal & $\begin{array}{l}\text { Política Nacional } \\
\text { de Assistência } \\
\text { Técnica aos } \\
\text { Empreendimentos } \\
\text { Econômicos } \\
\text { Solidários }\end{array}$ & $\begin{array}{l}\text { Visa assessorar trabalhadores em regime de autogestão nos } \\
\text { processos de recuperação de empresas. Beneficiam milhares } \\
\text { de trabalhadores nos segmentos da apicultura, algodão } \\
\text { agroecológico, da coleta e reciclagem, entre outros. }\end{array}$ & $\begin{array}{l}\text { Roberto } \\
\text { Marinho Alves } \\
\quad \text { da Silva }\end{array}$ & 2011 \\
\hline Federal & $\begin{array}{c}\text { Incubadoras } \\
\text { Tecnológicas de } \\
\text { Cooperativas } \\
\text { Populares }\end{array}$ & $\begin{array}{l}\text { Alunos, professores e funcionários das universidades são } \\
\text { estimulados a organizar populações carentes em } \\
\text { cooperativas para garantir acesso a trabalho e renda. }\end{array}$ & $\begin{array}{l}\text { Gustavo Luis } \\
\text { Gutierrez }\end{array}$ & 2004 \\
\hline Federal & $\begin{array}{l}\text { Mapeamento } \\
\text { Nacional da } \\
\text { Economia } \\
\text { Solidária }\end{array}$ & $\begin{array}{l}\text { Política que visou mapear a economia solidária em todo o } \\
\text { país, possibilitando a construção de definições sobre } \\
\text { economia solidária, empreendimento de economia solidária } \\
\text { (EES), redes e complexos de empreendimentos, órgãos de } \\
\text { fomento da economia solidária. O mapeamento é } \\
\text { importante para fomentar e facilitar ações em prol da } \\
\text { economia solidária. }\end{array}$ & Paul Singer & 2009 \\
\hline Federal & Brasil Local & $\begin{array}{l}\text { O programa conta com agentes de desenvolvimento } \\
\text { solidário que assumem a responsabilidade de identificar } \\
\text { potencialidades e dificuldades dos empreendimentos de } \\
\text { economia solidária para dar assistência, mobilizando } \\
\text { políticas nas três esferas governamentais. }\end{array}$ & Paul Singer & 2009 \\
\hline Federal & $\begin{array}{l}\text { Programa } \\
\text { Nacional de } \\
\text { Incubadoras de } \\
\text { Cooperativas } \\
\text { Populares } \\
\text { (Proninc) }\end{array}$ & $\begin{array}{l}\text { As Incubadoras Tecnológicas de Cooperativas Populares } \\
\text { (ITCP) é um empreendimento de professores e alunos } \\
\text { dispostos a incubarassociados para criar em conjunto fontes } \\
\text { de trabalho e renda, partindo de princípios de economia } \\
\text { solidária. O programa surgiu em 1998, e inicialmente, } \\
\text { ofereceu ajuda para } 5 \text { universidades criarem suas ITCPs, } \\
\text { contando com o apoio da Financiadora de Estudos e Projetos } \\
\text { (Finep), Banco do Brasil, Fundação Banco do Brasil e Centro } \\
\text { de Orientação e Encaminhamento Profissional (Coepe). E em } \\
\text { 2003, houve ampliação do programa e hoje ultrapassa o } \\
\text { número de } 80 \text { ITCPs no país. }\end{array}$ & Paul Singer & 2009 \\
\hline Federal & $\begin{array}{l}\text { Programa } \\
\text { Economia } \\
\text { Solidária em } \\
\text { Desenvolvimento }\end{array}$ & $\begin{array}{l}\text { Implementado pelo governo federal entre os anos de 2004- } \\
2007 \text { e integrou as necessidades do movimento de Economia } \\
\text { Solidária, que estavam sendo discutidas pelo Fórum } \\
\text { Brasileiro e pelas resoluções da I Conferência Nacional e do } \\
\text { Conselho Nacional. }\end{array}$ & $\begin{array}{l}\text { Jacob Carlos } \\
\text { Lima }\end{array}$ & 2015 \\
\hline Federal & $\begin{array}{l}\text { Programa } \\
\text { Nacional de } \\
\text { Fomento às } \\
\text { Cooperativas de } \\
\text { Trabalho - } \\
\text { PRONACOOP } \\
\end{array}$ & $\begin{array}{l}\text { Programa com foco nas cooperativas que procura apoiar o } \\
\text { desenvolvimento e a melhoria do desempenho econômico e } \\
\text { social das mesmas. }\end{array}$ & $\begin{array}{l}\text { Jacob Carlos } \\
\text { Lima }\end{array}$ & 2015 \\
\hline Federal & $\begin{array}{l}\text { Programa } \\
\text { Nacional de } \\
\text { Incubadoras de } \\
\text { Cooperativas } \\
\text { Populares } \\
\text { (Proninc) } \\
\end{array}$ & $\begin{array}{l}\text { Programa iniciado em } 1998 \text { para estimular a criação de } \\
\text { incubadoras nas universidades brasileiras. Em 2007, já } \\
\text { apoiava } 33 \text { instituições localizadas em } 17 \text { unidades da } \\
\text { federação. }\end{array}$ & $\begin{array}{l}\text { Leonardo } \\
\text { Pamplona }\end{array}$ & 2009 \\
\hline Federal & $\begin{array}{l}\text { Programa } \\
\text { Economia } \\
\text { Solidária em } \\
\text { Desenvolvimento } \\
\end{array}$ & $\begin{array}{l}\text { Programa inserido no Plano Plurianual (PPA) do governo } \\
\text { federal (2004-2007) o que gerou orçamento próprio para a } \\
\text { Secretaria Nacional Economia Solidária e possibilitou a } \\
\text { implementação de ações de fomento a Economia Solidária. }\end{array}$ & $\begin{array}{l}\text { Leonardo } \\
\text { Pamplona }\end{array}$ & 2009 \\
\hline Federal & $\begin{array}{l}\text { Programa } \\
\text { Economia } \\
\text { Solidária em } \\
\text { Desenvolvimento }\end{array}$ & $\begin{array}{l}\text { Objetiva fortalecer e divulgar a economia solidária. É a } \\
\text { principal ação realizada pela Secretaria Nacional de } \\
\text { Economia Solidária no âmbito de política pública para essa } \\
\text { finalidade. Direciona-se ações para gerar trabalho e renda, } \\
\text { inclusão social e desenvolvimento. }\end{array}$ & $\begin{array}{l}\text { Creusa da Silva } \\
\text { Melo }\end{array}$ & 2012 \\
\hline Federal & $\begin{array}{l}\text { Programa } \\
\text { Economia } \\
\text { Solidária em } \\
\text { Desenvolvimento } \\
\end{array}$ & $\begin{array}{l}\text { Políticas integradas para articular formas de consolidar e } \\
\text { promover a Economia Solidária. }\end{array}$ & $\begin{array}{l}\text { Erika Porceli } \\
\quad \text { Alaniz }\end{array}$ & 2012 \\
\hline
\end{tabular}




\begin{tabular}{|c|c|c|c|c|}
\hline $\begin{array}{l}\text { Esfera } \\
\text { Política }\end{array}$ & Nome Programa & Descrição do Programa & $\begin{array}{l}\text { Autor(es) do } \\
\text { Estudo } \\
\text { Científico }\end{array}$ & $\begin{array}{c}\text { Ano } \\
\text { Publicação }\end{array}$ \\
\hline Federal & $\begin{array}{l}\text { Programa } \\
\text { Nacional de } \\
\text { Incubadoras de } \\
\text { Cooperativas } \\
\text { Populares - } \\
\text { PRONINC }\end{array}$ & $\begin{array}{l}\text { Programa que passou a ser coordenado pela Secretaria } \\
\text { Nacional de Economia Solidária em articulação com outros } \\
\text { ministérios, a partir de } 2003 \text {. }\end{array}$ & $\begin{array}{c}\text { Erika Porceli } \\
\text { Alaniz }\end{array}$ & 2012 \\
\hline Federal & $\begin{array}{l}\text { Programa } \\
\text { Economia } \\
\text { Solidária em } \\
\text { Desenvolvimento }\end{array}$ & $\begin{array}{l}\text { Programa com políticas direcionadas para assegurar } \\
\text { recursos financeiros, qualificação, suporte técnico } \\
\text { apropriado e mecanismos de comercialização de produtos. }\end{array}$ & $\begin{array}{l}\text { Édi A. Benini } \\
\text { Maurício Sardá } \\
\text { de Faria } \\
\text { Henrique T. } \\
\text { Novaes } \\
\text { Renato Dagnino }\end{array}$ & 2011 \\
\hline $\begin{array}{l}\text { Federal e } \\
\text { Estadual }\end{array}$ & $\begin{array}{l}\text { Programa de } \\
\text { Apoio a Projetos } \\
\text { Produtivos } \\
\text { Solidários }\end{array}$ & $\begin{array}{l}\text { Em parceria com o Banco do Nordeste (BNB), a SENAES/MTE } \\
\text { e o Ministério do Desenvolvimento Social e Combate à Fome } \\
\text { o programa apoia às organizações, que atuam com Fundos } \\
\text { Rotativos Solidários. Fornece recursos financeiros de ações } \\
\text { produtivas associativas e sustentáveis na Região Nordeste e } \\
\text { no Norte de Minas Gerais. A iniciativa expandiu-se para } \\
\text { apoiar a mais } 250 \text { Fundos Rotativos Solidários do Brasil, a } \\
\text { partir de } 2010 .\end{array}$ & $\begin{array}{l}\text { Roberto } \\
\text { Marinho Alves } \\
\quad \text { da Silva }\end{array}$ & 2011 \\
\hline Estadual & $\begin{array}{l}\text { Programa de } \\
\text { Economia Popular } \\
\text { Solidária } \\
\text { (ECOPOPSOL) do } \\
\text { Governo do } \\
\text { Estado do Rio } \\
\text { Grande do Sul } \\
(1998 / 2002) \\
\end{array}$ & $\begin{array}{l}\text { Fomenta a formação e aprendizado em autogestão, } \\
\text { melhoria do processo produtivo, financiamento, } \\
\text { comercialização e incubadoras de empreendimentos. Em } \\
\text { diversos ramos de produção e serviços, foram estabelecidos } \\
\text { e auxiliados mais de } 180 \text { empreendimentos econômicos } \\
\text { solidários. Formou-se mais de } 33 \text { redes de cooperação em } \\
\text { todo o Estado do Rio Grande do Sul, envolvendo cerca de } 700 \\
\text { empreendimentos. }\end{array}$ & $\begin{array}{c}\text { Sandro Pereira } \\
\text { Silva }\end{array}$ & 2009 \\
\hline Estadual & $\begin{array}{l}\text { Programa Bahia } \\
\text { Solidária }\end{array}$ & $\begin{array}{l}\text { O programa visa estimular a economia solidária, fortalecer o } \\
\text { associativismo e cooperativismo, para isso desenvolve ações } \\
\text { de incentivo, crédito, capacitação e divulgação com políticas } \\
\text { para gerar trabalho e renda, desenvolvimento justo e } \\
\text { solidário com cidadania. }\end{array}$ & $\begin{array}{l}\text { Péricles } \\
\text { Cerqueira } \\
\text { Monteiro }\end{array}$ & 2009 \\
\hline Estadual & $\begin{array}{l}\text { Programa } \\
\text { Estadual de } \\
\text { Incubadoras } \\
\text { Públicas - Bahia }\end{array}$ & $\begin{array}{l}\text { Fomenta empreendimentos populares e solidários que são } \\
\text { norteados pela autossustentabilidade e por princípios de } \\
\text { cooperativismo e economia solidária. }\end{array}$ & $\begin{array}{l}\text { Péricles } \\
\text { Cerqueira } \\
\text { Monteiro }\end{array}$ & 2009 \\
\hline Estadual & $\begin{array}{l}\text { Programa Boa } \\
\text { Pesca - Bahia }\end{array}$ & $\begin{array}{l}\text { Nas comunidades pesqueiras, visava formar agentes para } \\
\text { desenvolver práticas solidárias e difundir os conhecimentos, } \\
\text { com base na construção coletiva e no desenvolvimento local. }\end{array}$ & $\begin{array}{l}\text { Péricles } \\
\text { Cerqueira } \\
\text { Monteiro }\end{array}$ & 2009 \\
\hline Estadual & $\begin{array}{l}\text { Programa de } \\
\text { Economia Popular } \\
\text { e Solidária - Rio } \\
\text { Grande do Sul }\end{array}$ & $\begin{array}{l}\text { Experiência pioneira no âmbito estadual, criado em 1999, o } \\
\text { programa é voltado para a formação de cooperativas e } \\
\text { recuperação de empresas falidas. Como resultado já } \\
\text { orientou e estruturou, com base na autogestão, cerca de } 120 \\
\text { cooperativas no período, em variados ramos de produção e } \\
\text { serviços. }\end{array}$ & $\begin{array}{l}\text { Leonardo } \\
\text { Pamplona }\end{array}$ & 2009 \\
\hline Estadual & $\begin{array}{l}\text { Programa de } \\
\text { Economia Popular } \\
\quad \text { Solidária } \\
\text { (ECOPOPSOL) - } \\
\text { Rio Grande do Sul }\end{array}$ & $\begin{array}{l}\text { O programa Economia Popular Solidária do Rio Grande do Sul } \\
\text { foi primeiro programa no Brasil, realmente estruturado, a } \\
\text { manifestar a economia solidária como estratégia de política } \\
\text { pública. }\end{array}$ & $\begin{array}{l}\text { Sandro Pereira } \\
\text { Silva e } \\
\text { Fernanda Abreu } \\
\text { Nagem }\end{array}$ & 2011 \\
\hline Estadual & $\begin{array}{l}\text { Incubadora } \\
\text { Tecnológica de } \\
\text { Cooperativas } \\
\text { Populares da } \\
\text { Universidade do } \\
\text { Vale do Itajaí - } \\
\text { ITCP/UNIVALI }\end{array}$ & $\begin{array}{l}\text { Incubadora atua na formação da Rede de Políticas Públicas e } \\
\text { tem como principal estratégia a organização dos processos } \\
\text { de articulação e incentivo das políticas públicas em Economia } \\
\text { Solidária dos empreendimentos assessorados pela } \\
\text { incubadora que compreendem os municípios da região } \\
\text { litorânea do estado de Santa Catarina. }\end{array}$ & $\begin{array}{l}\text { Géssica Peres e } \\
\text { Leila Andrésia } \\
\text { Severo Martins }\end{array}$ & 2014 \\
\hline Municipal & $\begin{array}{l}\text { Programa } \\
\text { Oportunidade } \\
\text { Solidária (OS) da } \\
\quad \text { Prefeitura } \\
\text { Municipal de São } \\
\quad \text { Paulo } \\
\text { (2001/2004) }\end{array}$ & $\begin{array}{l}\text { O programa visa de uma forma distinta da lógica do } \\
\text { assalariamento, combater o desemprego e a pobreza na } \\
\text { cidade de São Paulo, fornecendo aos grupos de } \\
\text { trabalhadores a base necessária para a formação de } \\
\text { empreendimentos autogestionários. Ele esteve presente em } \\
45 \text { de } 96 \text { Distritos Administrativos no município, e foi } \\
\text { implantado pelas chamadas Instituições Parceiras }\end{array}$ & $\begin{array}{c}\text { Sandro Pereira } \\
\text { Silva }\end{array}$ & 2009 \\
\hline
\end{tabular}




\section{p. 67 - Políticas Públicas de Economia Solidária: uma Revisão da Literatura}

\begin{tabular}{|c|c|c|c|c|}
\hline $\begin{array}{l}\text { Esfera } \\
\text { Política }\end{array}$ & Nome Programa & Descrição do Programa & $\begin{array}{l}\text { Autor(es) do } \\
\text { Estudo } \\
\text { Científico }\end{array}$ & $\begin{array}{c}\text { Ano } \\
\text { Publicação }\end{array}$ \\
\hline & & $\begin{array}{l}\text { Incubadoras (IPI), formadas por ONG, Universidades e a } \\
\text { ANTEAG. No total, foram contratadas } 15 \text { entidades } \\
\text { executoras, além de centenas de agentes multiplicadores } \\
\text { que trabalhavam na formação. }\end{array}$ & & \\
\hline Municipal & $\begin{array}{l}\text { Programa } \\
\text { Associação de } \\
\text { Recicladores de } \\
\text { Caxias do Sul } \\
\end{array}$ & $\begin{array}{l}\text { Em Caxias do Sul para gerar trabalho e renda, dá-se } \\
\text { assistência à associação de recicladores visando a auto- } \\
\text { sustentação das famílias envolvidas. }\end{array}$ & $\begin{array}{l}\text { Edi Augusto } \\
\text { Benini }\end{array}$ & 2004 \\
\hline Municipal & $\begin{array}{l}\text { Programa Mutirão } \\
\text { em Autogestão } \\
\text { em Ipatinga-MG }\end{array}$ & $\begin{array}{l}\text { Em Ipatinga, para a construção de moradia, coloca-se em } \\
\text { prática a experiência autogestionária. O programa municipal } \\
\text { constrói moradias por mutirão sob gestão de entidades } \\
\text { comunitárias. }\end{array}$ & $\begin{array}{c}\text { Edi Augusto } \\
\text { Benini }\end{array}$ & 2004 \\
\hline Municipal & $\begin{array}{l}\text { Projeto educação } \\
\text { para o trabalho e } \\
\text { a cidadania (PETC) } \\
\text { em Porto Alegre - } \\
\text { RS }\end{array}$ & $\begin{array}{l}\text { Na cidade de Porto Alegre a inciativa tem o intuito de } \\
\text { qualificar trabalhadores sem acesso ao sistema tradicional } \\
\text { de formação profissional, criam-se formas para gerar } \\
\text { trabalho e renda, em regime de autogestão. O foco da } \\
\text { política é à população de baixa renda, desempregada e com } \\
\text { idade superior. }\end{array}$ & $\begin{array}{c}\text { Edi Augusto } \\
\text { Benini }\end{array}$ & 2004 \\
\hline Municipal & $\begin{array}{l}\text { Programa Grupo } \\
\text { comunitário de } \\
\text { autogestão em } \\
\text { Joaquim Távora - } \\
\text { MG } \\
\end{array}$ & $\begin{array}{l}\text { Para tentar reduzir problemas de falta de recursos de } \\
\text { pequenos produtores e ociosidade de mão-de-obra, o } \\
\text { programa visa gerar emprego, renda e incentivar grupos } \\
\text { formais e informais de autogestão. }\end{array}$ & $\begin{array}{l}\text { Edi Augusto } \\
\text { Benini }\end{array}$ & 2004 \\
\hline Municipal & $\begin{array}{l}\text { Programa } \\
\text { Capacitação em } \\
\text { Autogestão em } \\
\text { Fortaleza - CE } \\
\end{array}$ & $\begin{array}{l}\text { O programa objetiva fortificar a organização dos artesãos, } \\
\text { fornecer assessoria técnica e gerencial para } \\
\text { aperfeiçoamento da comercialização, autogestão e } \\
\text { sustentação do empreendimento. }\end{array}$ & $\begin{array}{c}\text { Edi Augusto } \\
\text { Benini }\end{array}$ & 2004 \\
\hline Municipal & $\begin{array}{l}\text { Programa } \\
\text { Associação de } \\
\text { Recicladores em } \\
\text { Caxias do Sul - RS }\end{array}$ & $\begin{array}{l}\text { O programa tem parcerias com várias ONGs e compreende } \\
180 \text { famílias de Caxias do Sul-RS. A associação de recicladores } \\
\text { tem como base a idealização da cidadania por meio do } \\
\text { acesso ao trabalho de forma coletiva e autogestionária, e a } \\
\text { contribuição com a preservação do meio ambiente. }\end{array}$ & $\begin{array}{c}\text { Edi Augusto } \\
\text { Benini }\end{array}$ & 2004 \\
\hline Municipal & $\begin{array}{l}\text { Programa de } \\
\text { desenvolvimento } \\
\text { local em Piraí - RJ }\end{array}$ & $\begin{array}{l}\text { Com atuação nas áreas industrial, agrícola e de cooperativa, } \\
\text { o programa incentiva empreendimentos econômicos. } \\
\text { Desenvolve a integração de empreendimentos populares às } \\
\text { cadeias produtivas, assegurando acesso a crédito, } \\
\text { capacitação e assessoria técnica, além de estabelecer selo de } \\
\text { comércio solidário. }\end{array}$ & $\begin{array}{l}\text { Edi Augusto } \\
\text { Benini }\end{array}$ & 2004 \\
\hline Municipal & $\begin{array}{l}\text { Programa Grupo } \\
\text { de artesões } \\
\text { Cooperados em } \\
\text { Santos - SP }\end{array}$ & $\begin{array}{l}\text { A meta é a autosustentação dos grupos com uma proposta } \\
\text { de cooperativa de produção, explorando a identidade } \\
\text { turística da cidade, para isso promove a capacitação, } \\
\text { profissionalização e viabilização da geração de renda por } \\
\text { meio do artesanato local. }\end{array}$ & $\begin{array}{l}\text { Edi Augusto } \\
\text { Benini }\end{array}$ & 2004 \\
\hline Municipal & $\begin{array}{l}\text { Projeto Cooperar } \\
\quad \text { em } \\
\text { Fortaleza-CE }\end{array}$ & $\begin{array}{l}\text { Refere-se a uma incubadora de empreendimentos de } \\
\text { economia solidária que assessora no estabelecimento de } \\
\text { redes de organizações solidárias para uma gestão com } \\
\text { desenvolvimento sustentável, utilizando tecnologia } \\
\text { tradicional e de ponta. }\end{array}$ & $\begin{array}{l}\text { Edi Augusto } \\
\text { Benini }\end{array}$ & 2004 \\
\hline Municipal & $\begin{array}{l}\text { Programa Agência } \\
\text { de fomento } \\
\text { do Amapá s/a em } \\
\text { Macapá - AP } \\
\end{array}$ & $\begin{array}{l}\text { O programa fornece, a empreendedores populares que } \\
\text { visam ter o próprio negócio, mecanismos e ferramentas de } \\
\text { crédito para fortalecer a cultura empreendedora, popular e } \\
\text { solidária. }\end{array}$ & $\begin{array}{l}\text { Edi Augusto } \\
\text { Benini }\end{array}$ & 2004 \\
\hline Municipal & $\begin{array}{l}\text { Projeto Banco do } \\
\text { Povo de Recife em } \\
\text { Recife - PE }\end{array}$ & $\begin{array}{l}\text { Desenvolve uma política de crédito para a Economia Popular } \\
\text { e Solidária, direciona, capacita e qualifica empreendedores, } \\
\text { buscando a melhoria técnica, gerencial e a sustentabilidade } \\
\text { dos negócios. }\end{array}$ & $\begin{array}{c}\text { Edi Augusto } \\
\text { Benini }\end{array}$ & 2004 \\
\hline Municipal & $\begin{array}{l}\text { Programa Redes } \\
\text { de cooperação } \\
\text { em Porto Alegre - } \\
\text { RS }\end{array}$ & $\begin{array}{l}\text { Impulsiona a prática de ação conjunta, formando redes } \\
\text { interorganizacionais, para fortalecer micro e pequenas } \\
\text { empresas. Oferecem parcerias com universidades, } \\
\text { metodologia específica, consultores especializados e suporte } \\
\text { técnico para o bom resultado das redes. }\end{array}$ & $\begin{array}{l}\text { Edi Augusto } \\
\text { Benini }\end{array}$ & 2004 \\
\hline Municipal & $\begin{array}{c}\text { Programa Rede de } \\
\text { Economia }\end{array}$ & $\begin{array}{l}\text { Em Camaçari, os beneficiários do programa recebem } \\
\text { acompanhamento, apoio e orientação na gestão dos } \\
\text { empreendimentos, qualificação dos produtos, }\end{array}$ & $\begin{array}{c}\text { Edi Augusto } \\
\text { Benini }\end{array}$ & 2004 \\
\hline
\end{tabular}




\begin{tabular}{|c|c|c|c|c|}
\hline $\begin{array}{l}\text { Esfera } \\
\text { Política }\end{array}$ & Nome Programa & Descrição do Programa & $\begin{array}{l}\text { Autor(es) do } \\
\text { Estudo } \\
\text { Científico }\end{array}$ & $\begin{array}{c}\text { Ano } \\
\text { Publicação }\end{array}$ \\
\hline & $\begin{array}{l}\text { Solidária em } \\
\text { Camaçari - BA }\end{array}$ & $\begin{array}{l}\text { comercialização e formação das redes de produção. É uma } \\
\text { estratégia de combate à pobreza e de promoção social. }\end{array}$ & & \\
\hline Municipal & $\begin{array}{l}\text { Programa de } \\
\text { Incubadora de } \\
\text { cooperativas em } \\
\text { Embu - SP }\end{array}$ & $\begin{array}{l}\text { Busca a inserção no mercado de trabalho da população de } \\
\text { baixa renda desempregada, para isso, organiza, forma e } \\
\text { profissionaliza cooperativas diversas, como de prestação de } \\
\text { serviço, construção, condutores e guardadores de carro, } \\
\text { artesanato. }\end{array}$ & $\begin{array}{l}\text { Edi Augusto } \\
\text { Benini }\end{array}$ & 2004 \\
\hline Municipal & $\begin{array}{l}\text { Programa de } \\
\text { Cooperativismo } \\
\text { de trabalho, } \\
\text { administração, } \\
\text { gestão e } \\
\text { cidadania em } \\
\text { Maringá - PR }\end{array}$ & $\begin{array}{l}\text { O programa acompanha e assessora, a organização das } \\
\text { mulheres do bairro em torno de uma cooperativa de } \\
\text { confecção e facção dentro do princípio da Economia } \\
\text { Solidária. }\end{array}$ & $\begin{array}{l}\text { Edi Augusto } \\
\text { Benini }\end{array}$ & 2004 \\
\hline Municipal & $\begin{array}{c}\text { Programa de } \\
\text { educação } \\
\text { cooperativa a } \\
\text { união faz a vida - } \\
\text { projetos } \\
\text { cooperativos e } \\
\text { ambientais em } \\
\text { Santa Bárbara do } \\
\text { Sul - RS }\end{array}$ & $\begin{array}{l}\text { Propaga o espírito de cooperativismo dentro da temática de } \\
\text { meio ambiente, levando a ideia às escolas de ensino } \\
\text { fundamental por meio de cursos, seminários, palestras, } \\
\text { trabalho em grupo, encontro de coordenadores e visita às } \\
\text { escolas. }\end{array}$ & $\begin{array}{l}\text { Edi Augusto } \\
\text { Benini }\end{array}$ & 2004 \\
\hline Municipal & $\begin{array}{l}\text { Programa de Ação } \\
\text { Integrada - PAI } \\
\text { em Diadema - SP }\end{array}$ & $\begin{array}{l}\text { No município de Diadema-SP, as ações partem de diferentes } \\
\text { secretariam e departamentos da prefeitura para erradicação } \\
\text { da pobreza e inclusão de trabalhadores adultos } \\
\text { desempregados no mercado, dessa maneira, promovem } \\
\text { qualificação profissional e fomenta negócios coletivos com } \\
\text { os princípios da economia solidária. }\end{array}$ & $\begin{array}{l}\text { Edi Augusto } \\
\text { Benini }\end{array}$ & 2004 \\
\hline Municipal & $\begin{array}{l}\text { Projeto de } \\
\text { geração de } \\
\text { emprego e renda } \\
\text { em Pirapora - MG }\end{array}$ & $\begin{array}{l}\text { O público alvo do programa são pessoas sem ou com baixa } \\
\text { renda, e busca a organização em formas coletivas de } \\
\text { trabalho. Promove-se curso de capacitação profissional, } \\
\text { oficinas de autogestão, assessoria na legalização e regulação } \\
\text { de documentos e registros. }\end{array}$ & $\begin{array}{l}\text { Edi Augusto } \\
\text { Benini }\end{array}$ & 2004 \\
\hline Municipal & $\begin{array}{l}\text { Programa } \\
\text { Oportunidade } \\
\text { Solidária } \\
\text { Prefeitura de São } \\
\text { Paulo - SP }\end{array}$ & $\begin{array}{l}\text { Programa vinculado a Secretaria Municipal do } \\
\text { Desenvolvimento, Trabalho e Solidariedade em parceria com } \\
\text { as universidades, FGV e USP, por meio das Incubadoras } \\
\text { Tecnológicas de Cooperativas Populares. O intuito é } \\
\text { estimular a autogestão e o empreendedorismo pela } \\
\text { economia solidária. }\end{array}$ & $\begin{array}{l}\text { Edi Augusto } \\
\text { Benini }\end{array}$ & 2004 \\
\hline Municipal & $\begin{array}{l}\text { Programa } \\
\text { Incubadoras de } \\
\text { Cooperativas } \\
\text { Prefeitura } \\
\text { Municipal de } \\
\text { Santo André } \\
\end{array}$ & $\begin{array}{l}\text { Programa vinculado a Secretaria de Desenvolvimento e Ação } \\
\text { Regional - Departamento de Geração de Trabalho e Renda } \\
\text { que objetiva criação de cooperativas autênticas. Apoia } \\
\text { iniciativas de produção autogestionárias e melhoria da } \\
\text { distribuição de renda. }\end{array}$ & $\begin{array}{l}\text { Edi Augusto } \\
\text { Benini }\end{array}$ & 2004 \\
\hline Municipal & $\begin{array}{l}\text { Projeto Educação } \\
\text { para o Trabalho e } \\
\text { Cidadania (PETC), } \\
\text { o Projeto Ações } \\
\text { Coletivas (PAC) e } \\
\text { as Incubadoras } \\
\text { Populares de EES - } \\
\text { Porto Alegre-RS }\end{array}$ & $\begin{array}{l}\text { Fomenta ações de capacitação profissional, geração de } \\
\text { trabalho e renda por meio do cooperativismo e da economia } \\
\text { solidária, foi a primeira política pública local com esse } \\
\text { enfoque em empreendimentos econômicos solidárias, teve } \\
\text { início em 1994/1995, foi implementada pela Supervisão de } \\
\text { Economia Popular, ligada à Secretaria Municipal da Indústria } \\
\text { e Comércio }\end{array}$ & $\begin{array}{l}\text { Marina Farkas } \\
\text { Bitelman }\end{array}$ & 2008 \\
\hline Municipal & $\begin{array}{l}\text { Programa } \\
\text { Incubadora de } \\
\text { Cooperativas (PIC) } \\
\text { - Santo André } \\
\end{array}$ & $\begin{array}{l}\text { A Fundação Santo André implementou o programa e ele } \\
\text { integrava a política de economia solidária da prefeitura e } \\
\text { contava com outras parcerias. }\end{array}$ & $\begin{array}{l}\text { Marina Farkas } \\
\text { Bitelman }\end{array}$ & 2008 \\
\hline Municipal & $\begin{array}{l}\text { Programa } \\
\text { Oportunidade } \\
\text { Solidária - } \\
\text { Prefeitura São } \\
\text { Paulo }\end{array}$ & $\begin{array}{l}\text { O programa Oportunidade Solidária foi um dos pioneiros } \\
\text { programas públicos de Economia Solidária no Brasil e } \\
\text { procurava gerar oportunidades de trabalho e renda nesse } \\
\text { tipo de economia. }\end{array}$ & $\begin{array}{l}\text { Marina Farkas } \\
\text { Bitelman }\end{array}$ & 2008 \\
\hline
\end{tabular}




\section{p. 69 - Políticas Públicas de Economia Solidária: uma Revisão da Literatura}

\begin{tabular}{|c|c|c|c|c|}
\hline $\begin{array}{l}\text { Esfera } \\
\text { Política }\end{array}$ & Nome Programa & Descrição do Programa & $\begin{array}{l}\text { Autor(es) do } \\
\text { Estudo } \\
\text { Científico }\end{array}$ & $\begin{array}{c}\text { Ano } \\
\text { Publicação }\end{array}$ \\
\hline Municipal & $\begin{array}{l}\text { Programa Osasco } \\
\text { Solidária }\end{array}$ & $\begin{array}{l}\text { Implementado na gestão do município a partir de } 2005 \text {, } \\
\text { estimula a economia popular e solidária, assessorando o } \\
\text { estabelecimento desses empreendimentos. }\end{array}$ & $\begin{array}{l}\text { Marina Farkas } \\
\text { Bitelman }\end{array}$ & 2008 \\
\hline Municipal & $\begin{array}{l}\text { Programa } \\
\text { Oportunidade } \\
\text { Solidária - } \\
\text { Prefeitura } \\
\text { Municipal de São } \\
\text { Paulo } \\
\end{array}$ & $\begin{array}{l}\text { Na esfera municipal, foi um dos programas iniciais de maior } \\
\text { destaque, especialmente, devido ao grande desafio de ser } \\
\text { implementado na maior metrópole do país. }\end{array}$ & $\begin{array}{l}\text { Sandro Pereira } \\
\text { Silva e } \\
\text { Fernanda Abreu } \\
\quad \text { Nagem }\end{array}$ & 2011 \\
\hline Municipal & $\begin{array}{l}\text { Programa } \\
\text { Oportunidade } \\
\text { Solidária - São } \\
\quad \text { Paulo }\end{array}$ & $\begin{array}{l}\text { Política pública que objetiva a inclusão social com vistas ao } \\
\text { combate a pobreza como estratégia. }\end{array}$ & $\begin{array}{l}\text { Herton Ellery } \\
\text { Araújo e } \\
\text { Frederico A. } \\
\text { Barbosa da } \\
\quad \text { Silva }\end{array}$ & 2005 \\
\hline Municipal & $\begin{array}{l}\text { Incubadoras } \\
\text { Públicas de } \\
\text { Economia Popular } \\
\text { e Solidária }\end{array}$ & $\begin{array}{l}\text { Programa que traz grande avanço nas políticas públicas, uma } \\
\text { vez que foram criadas incubadoras para fomentar a } \\
\text { Economia Popular e Solidária, mas no domínio de prefeituras } \\
\text { municipais, como exemplo de Paulista-PE, Santo André-SP, } \\
\text { Osasco-SP, Mesquita-RJ e as do Estado da Bahia. }\end{array}$ & $\begin{array}{l}\text { Sandra Faé } \\
\text { Praxedes }\end{array}$ & 2009 \\
\hline Municipal & $\begin{array}{l}\text { Programa } \\
\text { Incubadora de } \\
\text { Cooperativas de } \\
\text { Santo André-SP }\end{array}$ & $\begin{array}{l}\text { Incubadora, criada na gestão do município entre os anos de } \\
\text { 1996-2000, de domínio da prefeitura municipal de Santo } \\
\text { André com parte integrante da política de geração de } \\
\text { trabalho e renda, no qual o Estado busca qualificar a } \\
\text { sociedade civil para gestão coletiva, participativa e } \\
\text { autônoma. }\end{array}$ & $\begin{array}{l}\text { Gabriela } \\
\text { Cavalcanti } \\
\text { Cunha }\end{array}$ & 2002 \\
\hline Municipal & $\begin{array}{c}\text { Programa } \\
\text { Oportunidade } \\
\text { Solidária - São } \\
\text { Paulo } \\
\end{array}$ & $\begin{array}{l}\text { Programa de incentivo ao empreendedorismo individual e } \\
\text { coletivo, além do cooperativismo e da prática } \\
\text { autogestionária. }\end{array}$ & $\begin{array}{l}\text { Gabriela } \\
\text { Cavalcanti } \\
\text { Cunha }\end{array}$ & 2002 \\
\hline
\end{tabular}

Fonte: Elaborado pelos autores. 